\title{
A case with internuclear ophthalmoplegia and intermittent exotropia
}

\section{Internükleer oftalmoplejili ve intermitan ekzotropyalı bir olgu}

\author{
*Raşit Kılıç ${ }^{1}$, Ali Kurt ${ }^{1}$, Berrin Yavuztürk ${ }^{2}$, Aysu Yetiş $^{3}$ \\ ${ }^{1}$ Department Of Eye Diseases, Ahi Evran University School of Medicine, Kırșehir, Turkey \\ ${ }^{2}$ Department of Emergency, Ahi Evran University Training and Research Hospital, Kırşehir, Turkey \\ ${ }^{3}$ Department of Neurology, Ahi Evran University Training and Research Hospital, Kırşehir, Turkey \\ Corresponding author: Dr. Raşit Kılıç, Göz Hastalıkları Anabilim Dalı, Ahi Evran Üniversitesi Tıp Fakültesi, TR-40200, \\ Kırşehir, Turkey \\ E-mail: kilicrasit@gmail.com \\ Received/Accepted: March 20, 2015/November 24, 2015 \\ Conflict of interest: There is not a conflict of interest.
}

\section{SUMMARY}

A 69-year-old woman was admitted to our emergency clinic with a head trauma and acute onset diplopia following a fall while walking at home. Ophthalmic examination revealed that visual acuity of 20/20 both eyes, pupillary reactions to light and fundus were normal. There was an adduction deficit of right eye and intermittent exotropia of left eye in primary gaze. Ductions were normal in left eye. Left hemiparesis and left positive babinsky were detected by neurological examination. The brain magnetic resonance imaging comfirmed the clinical diagnosis of internuclear ophthalmoplegia as a result of acute ischemic infarction affecting pontomesencephalic junction. The adduction deficit, exotropia and the other neurological symptoms resolved in 2 weeks duration. In conclusion, the acute onset of diplopia and exotropia in an old patient with vascular risk factors suggests probability of the acute ponto-mesencephalic junction infarction.

Keywords: Diplopia, exotropia, internuclear ophthalmoplegia

\section{ÖZET}

Ellidokuz yaşında kadın hasta kafa travması ve akut başlangıçlı çift görme şikayeti ile acil servise başvurdu. Oftalmik muayenesinde görme keskinliği her iki gözde 20/20, 1şığa karşı pupiller reaksiyonlar ve fundus normaldi. Sağ gözde addüksiyon kusuru ve sol gözde primer bakışta intermitan ekzotropya vardı. Sol göz hareketleri normaldi. Nörolojik muayenede sol hemiparezi ve sol babinski pozitifliği vardı. Beyin manyetik rezonans görüntüleme, klinik tanı internükleer oftalmoplejiyi doğrulayarak akut iskemik ponto-mezensefalik köşe infaktı ile uyumulu idi. Addüksiyon kusuru, ekzotropya ve diğer nörolojik bulgular 2 hafta içerisinde kayboldu. Sonuç olarak, vasküler risk faktörü olan yaşlı bir kadında akut başlayan çift görme ve ekzotropya akut ponto-mezensefalik köşe infaktı olasılı̆̆ınıda düşündürmelidir.

Anahtar sözcükler: Çift görme, egzotropya, internükleer oftalmopleji

\section{INTRODUCTION}

Horizontal eye movements are innervated by the oculomotor nerve and the abducens nerve and conducted by the medial rectus and the lateral rectus muscles ${ }^{1}$.The paramedian pontine reticular formation (PPRF) is located in the pontine tegmentum near the abducens nucleus ${ }^{2}$. PPRF contains excitatory neurons that produce the pulse transmitted to the ipsilateral abducens nu- cleus $^{3}$. Then, the signal projects to the abducens nerve and simultaneously to the contralateral oculomotor nucleus via the medial longitudinal fasciculus (MLF) ${ }^{4}$. MLF is a tract that is located in the posterior part of the pons, which interconnect between oculomotor and the abducens nuclei. By means of MLF, the oculomotor and the abducens nuclei functions are coordinated, in this way, conjugate horizontal 
eye movements ocur ${ }^{5}$.

The brainstem lesions can affect horizontal eye movements and cause various disorders. The horizontal eye movement disorders are three classes ${ }^{6}$. These disorders are lateral gaze palsy, internuclear ophthalmoplegia and one and a half syndrome that refers to the combination of ipsilateral lateral gaze palsy and internuclear ophthalmoplegia.

In this study, a case with suffering diplopia who presented to our emergency clinic with a head trauma following a fall while walking at home has been introduced.

\section{CASE REPORT}

A 69-year-old woman was admitted to our emergency clinic with a head trauma and acute onset diplopia following a fall while walking at home. Her medical history was remarkable for hipertension, diabetes mellitus and cerebrovascular disease. Ophthalmic examination revealed that visual acuity of 20/20 both eyes, pupillary reactions to light and fundus were normal There was an adduction deficit of right eye and intermittent exotropia of left eye in primary gaze. Ductions were normal in left eye. Left hemiparesis and left positive babinsky were detected by neurological examination. The brain magnetic resonance imaging (MRI) comfirmed the clinical diagnosis of INO as a result of acute ischemic infarction affecting pontomesencephalic junction (Figure 1). The adduction deficit, exotropia and the other neurological symptoms resolved in 2 weeks duration.
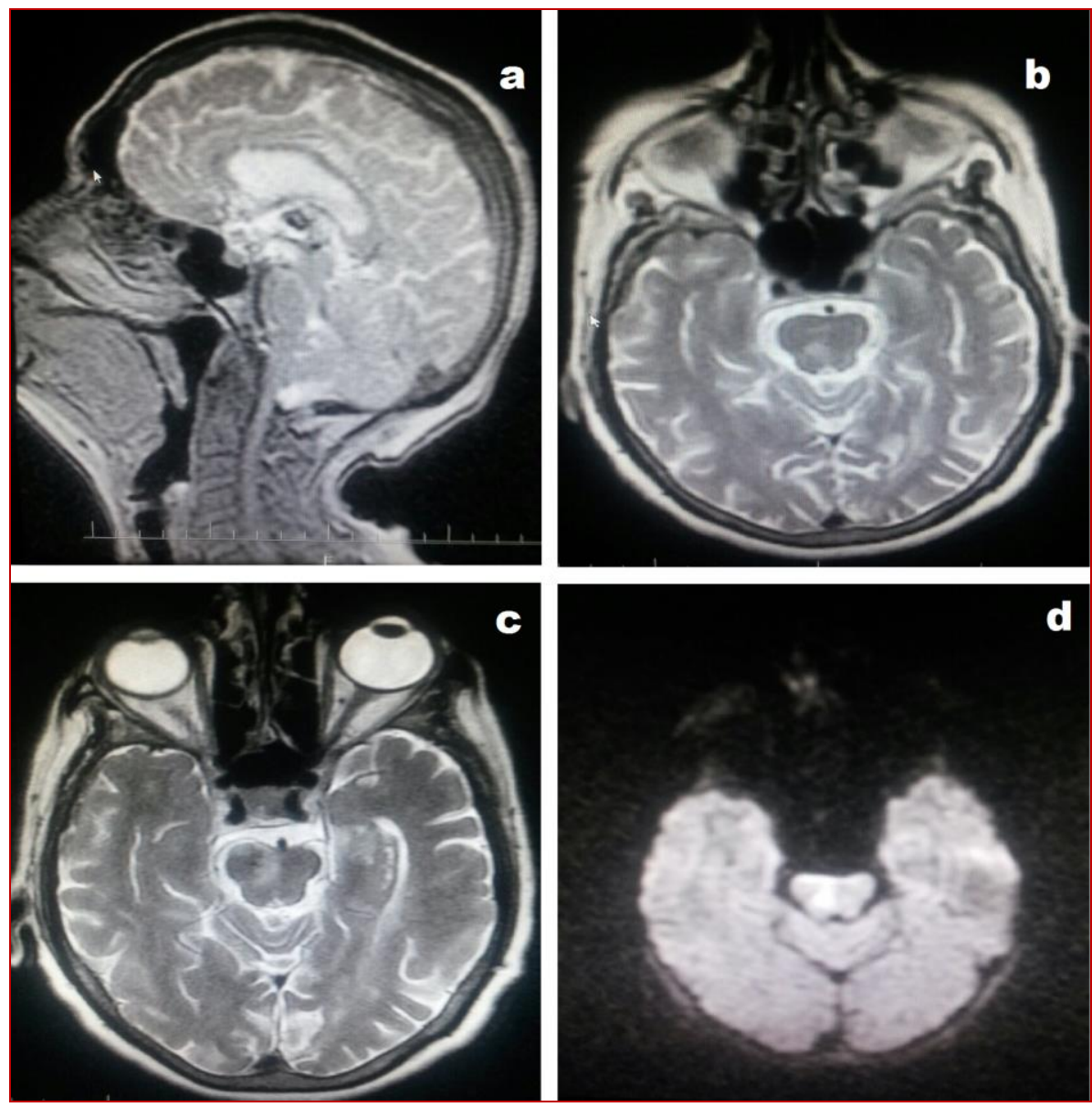

Figure 1 (a,b,c,d): Sagittal and axial MRI shows an infarct about $12 \mathrm{~mm}$ extent and diffusion MRI indicates acute infarction that focal area of diffusion restriction in the pontomesencephalic junction. 


\section{DISCUSSION}

Internuclear ophthalmoplegia (INO) is an eye movement disorder, characterized by the paresis of adduction of the ipsilateral eye and nystagmus of the contralateral eye toward the lateral gaze ${ }^{7}$. INO is occured by a lesion containing the MLF in the brainstem, the most common cause is a pontine infarction. However, the disorder can also occur as a result of diverse pathologies such as demyelinating, traumatic, infectious and neoplasic ${ }^{8}$. When both fascicles are affected in the brainstem, the INO is described bilateral. Wall-eyed bilateral internuclear ophthalmoplegia (WEBINO) is the other variant of INO. The WEBINO syndrome consist of bilateral adduction deficits, bilateral abducting nystagmus, primary gaze exotropia and loss of convergence ${ }^{9}$.

In some cases, exotropia accompanies unilateral INO and it occurs on the ipsilateral eye $^{10}$. However, exotropia atypically originated on the contralateral eye of the patient who was presented in this study. Hering's law of equal innervation explains that binocular conjugate eye movements are the result of each eye receiving similar conjugate motor innervations ${ }^{11}$. Excessive innervation of the ipsilateral medial rectus and its synchronized muscle of contralateral lateral rectus may cause intermittent exotropia on the contralateral eye. We think about the patient that she fall due to transient loss of consciousness after the acute pontomesencephalic junction infarction.

In conclusion; the acute onset of diplopia and exotropia in an old patient with vascular risk factors suggests probability of the acute ponto-mesencephalic junction infarction.

\section{REFERENCES}

1. Van Horn MR, Sylvestre PA, Cullen KE. The brainstem saccadic burst generator encodes gaze in three-dimensional space. Neurophysiol 2008; 100: 1967-82.

2. Horn AK. The reticular formation
Prog Brain Res 2006; 151: 127-55.

3. Cohen B, Komatsuzaki A. Eye movements induced by stimulation of the pontine reticular formation: evidence for integration in oculomotor pathways. Exp Neurol 1972; 36: 101-17.

4. Miller MJ, Mark LP, Ho KC, Haughton VM. Anatomic relationship of the oculomotor nuclear complex and medial longitudinal fasciculus in the midbrain. AJNR Am J Neuroradiol 1997; 18: 111-3.

5. Frohman TC, Galetta S, Fox R. Pearls \& oy-sters: The medial longitudinal fasciculus in ocular motor physiology. Neurology 2008; 70: 57-67.

6. Bae YJ, Kim YH, Choi BS, Jung C, Kim E. Brainstem pathways for horizontal eye movement: pathologic correlation with MR imaging. Radiographics 2013; 33: 4759.

7. Zee DS. Internuclear ophthalmoplegia: pathophysiology and diagnosis. Baillieres Clin Neurol 1992; 1: 455-70.

8. Bolaños I, Lozano D, Cantú C. Internuclear ophthalmoplegia: Causes and long-term follow-up in 65 patients. Acta Neurol Scand 2004; 110: 161-5.

9. Wu YT, Cafiero Chin M, Marques C. Wall-eyed bilateral internuclear ophthalmoplegia: review of pathogenesis, diagnosis, prognosis and management. Clin Exp Optom 2015; 98: 25-30.

10. Shaikh AG1, Ghasia FF, Rasouli G, DeGeorgia M, Sundararajan S. Acute onset of upbeat nystagmus, exotropia, and internuclear ophthalmoplegia atell-tale of pontomesencephalic infarct. J Neurol Sci 2013; 332: 56-8.

11. Ono H. Hering's law of equal innervation and vergence eye movement. Am J Optom Physiol Opt 1980; 57: 578-85. 